\title{
The Dominant and Recessive Forms of Cutis Laxa
}

\author{
PETER BEIGHTON*
}

\author{
St Thomas' Hospital, London
}

Cutis laxa is a very rare, genetically determined disorder of elastin, characterized clinically by a tendency of the skin to hang in loose folds, with the production of a typical grotesque facies and the appearance of premature ageing. These changes may be present at birth or may develop during infancy.

Systemic ramifications may be widespread and, in particular, the pulmonary and cardiovascular systems may be involved. Although less than 30 genuine cases have been reported there have been several instances of serious disability or death from cardiorespiratory complications. On the other hand, a significant proportion of the affected patients have lived comparatively normal existences.

In the course of a recent survey, in which complete ascertainment of all affected individuals in England and Wales was attempted, it became apparent that there were two forms of the condition,

Received 28 June 1971.

- Present address: Department of Human Genetics, Medical School, University of Cape Town, Republic of South Africa. one inherited as an autosomal dominant trait and the other as an autosomal recessive trait. The clinical features and prognosis differed considerably in these entities.

The purpose of the present paper is to show, by means of case reports and a review of the world literature, that these two forms of inherited cutis laxa are genetically and clinically distinct. In the autosomal dominant variety, complications are few and the life span is normal. Conversely, in the autosomal recessive type, there is a high incidence of illness and death in childhood from pulmonary and cardiac involvement.

\section{Cutis Laxa: Autosomal Dominant Inheritance} Kindred 1 (see Fig. 3)

IV.1., a white female, was born in 1940 after a full-term pregnancy and an uncomplicated delivery. The midwife noticed at the time of her birth that her skin was unusually soft and loose, but she was otherwise normal in every way.

As she grew older, the cutaneous laxity gradually

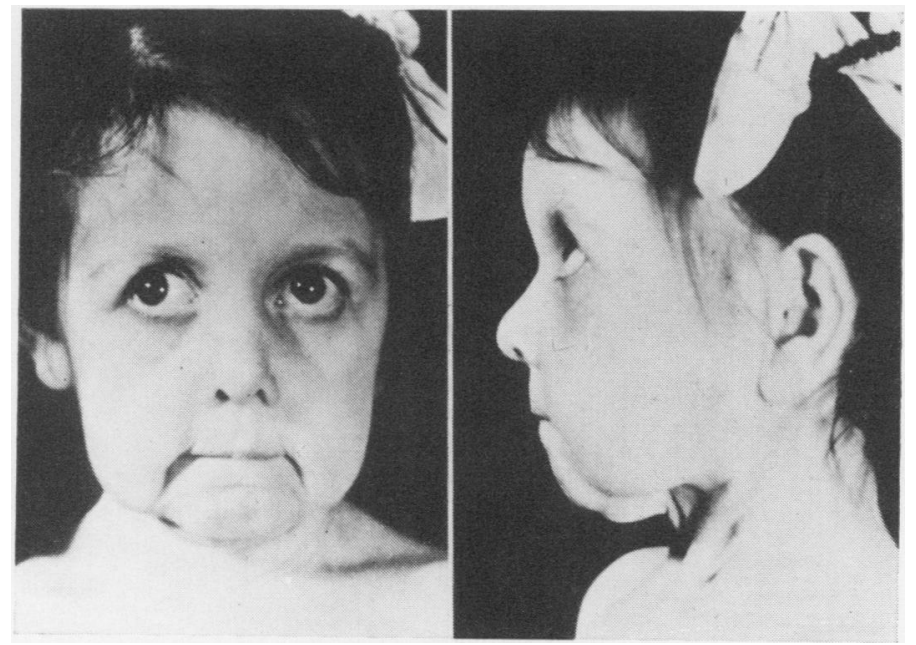

FIG. 1. IV.1. at the age of 6. Her skin hung in loose folds, giving her the appearance of an old woman. Her nose was hooked, with everted nostrils and a long upper lip. 
worsened. All areas of her body were affected, but the changes were most apparent in her face, where the skin hung in loose symmetrical folds, giving her the appearance of an old woman (Fig. 1). Indeed, she suffered greatly from teasing of her school fellows, who called her 'funny-face' or 'granny'.

Apart from pneumonia in early childhood, her general health remained good, and at the age of 6 , she had extensive plastic surgery to her face. There were no problems at operation, healing was rapid, and the end result was satisfactory. At this time, her case history was presented before the Royal Society of Medicine (Lewis, 1948).

Her later childhood was uneventful, and she did not have dyspnoea when she played games at school. In the second decade of her life, she had three more bouts of pneumonia, and at the age of 21 , bronchiectasis was diagnosed. Since that time, her pulmonary condition has only been a minor nuisance, causing slight dyspnoea on severe exertion and an intermittent productive cough.

She married and gave birth to a normal daughter. Later, 2 miscarriages occurred, each at 8 weeks, and subsequently, an affected daughter (V.4) was born. The patient was Rhesus negative, and antibodies developed during her last pregnancy. No complication occurred at her deliveries.

Examination in December 1969 revealed a cheerful, lively young woman, with a deep voice. Her nose was hooked, with everted nostrils, and her upper lip was long. Her facial skin was pendulous, her ears sagged, and her cheeks hung in smooth folds. She looked older than her years, but was by no means ugly or deformed. The skin of her body was soft and somewhat loose, and it tended to hang, particularly on her knees and elbows.

Her height was $167 \mathrm{~cm}$, her weight was $50 \cdot 8 \mathrm{~kg}$, and she was normally proportioned. Her hair and teeth were normal. There was no skeletal deformity, and the joints were not hypermobile. Crepitations were audible at the base of her left lung, but her cardiovascular system was normal. A right inguinal hernia was the only abdominal abnormality, and there were no abnormal signs in her central nervous system.

$V .4$, the second daughter of IV.1., was born in 1968. She weighed $2835 \mathrm{~g}$ and at birth her mother was able to make an immediate diagnosis of cutis laxa. The child's cutaneous features were very similar to those of her mother, but she was otherwise quite well.

When she was 6 months old, a systolic murmur was heard, and a tentative diagnosis of a small ventricular septal defect was made. However, she has remained a vigorous, happy child without any symptoms which might be referable to the heart or lungs.

On examination at the age of 18 months, she was a plump, intelligent infant, with lax skin on the upper eyelids, cheeks, neck, and trunk. These changes were of moderate degree, but she was affected more severely than her mother (Fig. 2). The hair, teeth, skeleton, and joints were normal, her voice was deep, and her nose and upper lip resembled those of the mother. The lungs

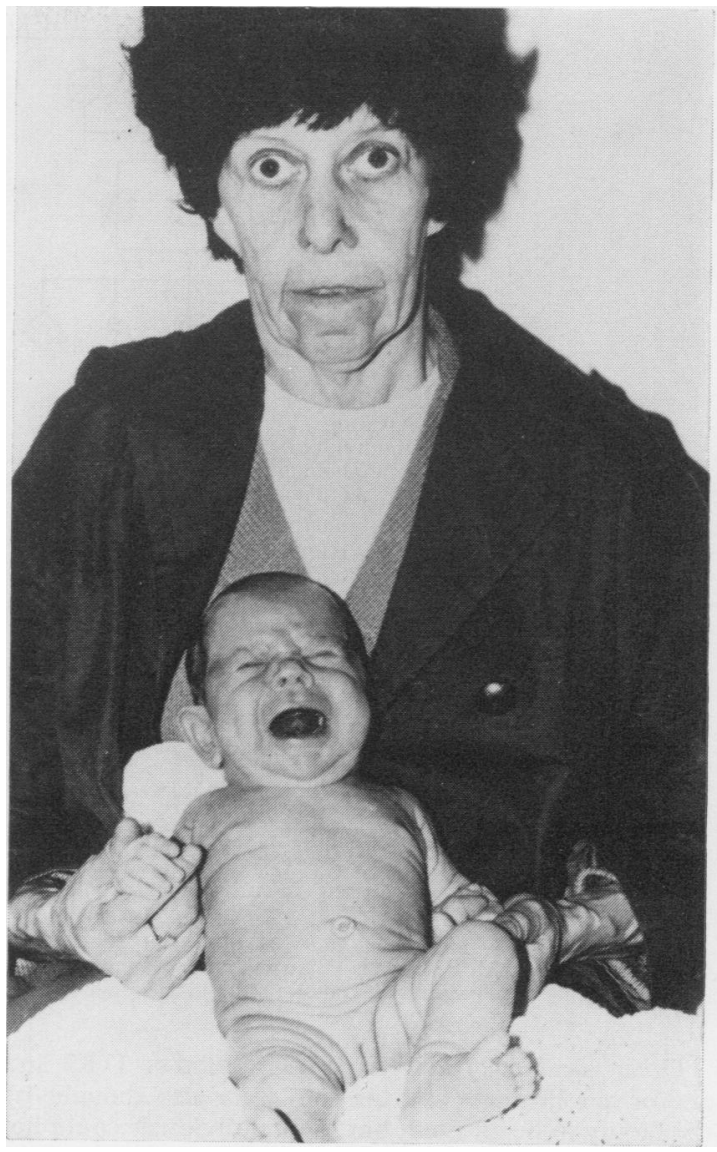

FIG. 2. Dominant cutis laxa. IV.1 and her daughter V.4. At the time that this picture was taken, IV.1 was 28 years of age, while V.4 was in early infancy. Due to the laxity of their facial skin, they both appeared to be much older.

and central nervous system were normal, but a systolic murmur was audible over the $3 \mathrm{rd}$ and 4 th intercostal spaces, at the left sternal edge.

III.2., the mother of IV.1., was noticed to have lax skin at her birth in 1920. Although she always looked much older than her true age, her condition had caused no great disability, and cosmetic surgery was never undertaken. The skin of all areas was affected, but the changes were maximal on her cheeks and neck.

Her general health was good, and operations for appendicitis, a left inguinal hernia, and a uterine prolapse were uneventful. She developed dyspnoea and a persistent cough in her late thirties, and bronchiectasis was diagnosed when she was 45 years of age.

The patient declined examination, but reports from her daughter's general practitioner, plastic surgeon, and paediatrician, together with a perusal of family photographs, established the diagnosis beyond any doubt. 
FIG. 3. Pedigrees. The pedigrees of kindreds 1 and 2 indicate autosomal dominant transmission of the trait. The presence of consanguinity in the other two pedigrees is suggestive of autosomal recessive inheritance.

Other members of kindred 1. The mother 111.2 and one of her brothers and his son, were also thought by the family to be affected, but these individuals could not be contacted (pedigree 1, Fig. 3).

\section{Kindred 2}

III.1., a white male, was born in 1962 after an uneventful pregnancy and a normal delivery. He weighed $2210 \mathrm{~g}$ at birth, and was apparently quite well.

He remained in good health during infancy but when he was one year old, a systolic murmur was heard, and it was suggested that he might have a small ventricular septal defect. The physician making this examination noted that he was of normal intelligence, plump, and 'looking older than his age'. By the age of 4 it was apparent that his skinfolds had become excessive, particularly on the cheeks and neck.

One year later the skin of his face, trunk, and limbs had become strikingly loose, and he had been teased at school because of his 'old man' appearance. His murmur was unchanged, and he had no symptoms of cardiac or pulmonary involvement. At this time his mother, who was then 29 years of age, was said to resemble a woman of 50 .

The diagnosis of cutis laxa was now made, and in addition to the mother, a study of the family indicated that an uncle and the maternal grandfather were also probably affected (pedigree 2, Fig. 3).

\section{Cutis Laxa: Autosomal Recessive Inheritance Kindred 3}

II.6., a white male, weighed $3742 \mathrm{~g}$ at his birth in 1965 , after a full-term pregnancy and normal delivery.

Pronounced dermal changes were apparent at this time; his skin hung in loose folds in all areas of his face, trunk, and limbs in such a way that it appeared to be 'too big for him'. In addition to his lugubrious facies and everted lower eyelids, he had the characteristic hooked nose, short columella, and long upper lip. His cry was hoarse and a huge obturator hernia was present. Persistent vomiting during the first week of life led to a diagnosis of pyloric stenosis. This abnormality was subsequently corrected at an uneventful operation.

When he was 3 weeks old radiography of the chest revealed gross emphysema, and an electrocardiogram showed evidence of considerable right ventricular hypertrophy.

By the end of his first year, he had had several episodes of pneumonia, and at this time there was radiographic evidence of considerable worsening of the emphysema. The electrocardiogram now indicated increased right ventricular hypertrophy and strain. The skin abnormalities were unchanged and his general health was very poor. His condition continued to deteriorate and he died in his second year, from cardiorespiratory complications.

His parents, who were first cousins, were clinically 
normal. Five elder brothers were also normal and no other members of the kindred were known to have cutaneous laxity (pedigree 3, Fig. 3).

\section{Kindred 4}

III.1., a white female, weighed $3288 \mathrm{~g}$ at her birth in 1965, which had followed a normal pregnancy and delivery.

At this time it was noted that she had lax skin in all regions of the body and limbs. She had a deep husky cry and the characteristic mournful facies. A loud systolic murmur was present over the praecordium and the thorax was hyper-resonant to percussion. There was no articular hypermobility, and the skin was neither fragile nor hyperelastic.

Her general health was poor during infancy and the early months of her life were punctuated by repeated chest infections. Her cutaneous condition gradually increased in severity. When she was 2 years of age, the family moved to another part of the country. Nothing is known of her subsequent progress.

The patient was the product of an incestuous union between her father and his own 15-year-old daughter. This daughter later married a young man and had a normal child. These individuals had no dermal abnormalities and there was no history of cutaneous laxity in any other members of the kindreds (pedigree 4, Fig. 3).

\section{Discussion}

The nosology of cutis laxa is complex, and among the many designations which have been employed are elastolysis, chalazoderma, and cutis pendula. Cutis laxa has often been confused with the EhlersDanlos syndrome, but this latter entity is readily differentiated by the presence of joint hypermobility, together with fragility and hyperextensibility of the skin (Beighton, 1970).
Inherited cutis laxa is also quite distinct from an acquired form of cutis laxa which develops later in life, sometimes after an ill-defined febrile illness. Patients affected by genetically determined cutis laxa have a hooked nose, with a long columella and everted nostrils, while in the other varieties of cutis laxa, the nose is normal in configuration (Beighton, Bull, and Edgerton, 1970).

Localized areas of loose skin may develop in neurofibromatosis and in atrophic scars which follow dermal lesions of granulomatous conditions such as syphilis and sarcoidosis. Circumscribed cutaneous laxity may also develop in affected regions in the late stages of pseudoxanthoma elasticum. On clinical examination, it is usually obvious that cutis laxa is a secondary manifestation in these disorders. This complex situation was clarified by Marshall, Vogelpoel, and Weber (1960), who proposed an excellent classification of the various forms of cutis laxa.

In many of the cases which have been reported in the world literature, there has been nothing to indicate a particular mode of inheritance of the disorder. However, in a proportion of these descriptions, there is evidence of either dominant or recessive transmission of the trait (Tables I and II).

The pedigrees of kindreds 1 and 2 (see Fig. 3) are consistent with autosomal dominant inheritance of cutaneous laxity. Equally, the family histories of the patients listed in Table I indicate dominant inheritance. It is noteworthy that the majority of these individuals enjoyed good health, apart from their dermal changes. Although some of them had pulmonary or cardiovascular manifestations, these were of mild degree, and caused little inconvenience.

TABLE I

DOMINANT INHERITANCE OF CUTIS LAXA

\begin{tabular}{|c|c|c|}
\hline Author & Clinical Features & Family History \\
\hline Graf (1836) & $\begin{array}{l}\text { Cutaneous laxity; no systemic ramifications; } \\
\text { onset in middle age }\end{array}$ & Grandfather, uncle, and aunt similarly affected \\
\hline $\begin{array}{l}\text { Rossbach (1884) } \\
\text { Kopp (1888) }\end{array}$ & $\begin{array}{l}\text { o Cutaneous laxity; onset at } 18 \\
\delta \text { Cutaneous laxity present at birth }\end{array}$ & $\begin{array}{l}\text { Affected son (Kopp's patient) } \\
\text { Affected father (Rossbach's patient) }\end{array}$ \\
\hline Talbot (1923) & $\begin{array}{l}\text { o Cutaneous laxity apparent in infancy; otherwise } \\
\text { healthy }\end{array}$ & Mother affected \\
\hline Lewis (1948) & $\begin{array}{l}\text { Loose skin since infancy; bilateral face lift } \\
\text { performed at the age of } 7\end{array}$ & Mother affected (see pedigree 1, Fig. 3 ) \\
\hline $\begin{array}{l}\text { Sestak (1962) } \\
\text { (patients depicted by Reidy } \\
\text { [1963]) }\end{array}$ & of Loose skin since birth; general health good & Affected father \\
\hline Balboni (1963) & $\begin{array}{l}\text { Cutaneous laxity apparent in infancy; health } \\
\text { good but angiography demonstrated } \\
\text { abnormalities of the aorta and great vessels }\end{array}$ & $\begin{array}{l}\text { Father and uncle affected; father had radiological } \\
\text { evidence of similar vascular abnormalities }\end{array}$ \\
\hline $\begin{array}{l}\text { Hayden, Talner, and Klaus } \\
\text { (1968) }\end{array}$ & $\begin{array}{l}\text { o Loose skin; pulmonary artery stenosis found in } \\
\text { early childhood }\end{array}$ & $\begin{array}{l}\text { Father, paternal aunt, grandmother, and great } \\
\text { grandmother affected }\end{array}$ \\
\hline
\end{tabular}


TABLE II

RECESSIVE INHERITANCE OF CUTIS LAXA

\begin{tabular}{l|l|l|l}
\hline \multicolumn{1}{c|}{ Author } & Clinical Features & Family History \\
\hline $\begin{array}{l}\text { Siegmund (1938) } \\
\begin{array}{c}\text { Fittke (1942) (patient restudied } \\
\text { by Theopold and Wildhack } \\
\text { [1951]) }\end{array}\end{array}$ & $\begin{array}{l}\text { Three affected sisters with loose skin and skeletal } \\
\text { abnormalities }\end{array}$ & Parents consanguineous; affected cousin \\
\hline $\begin{array}{l}\text { Cashman (1957) (kindred studied } \\
\text { by Sestak [1962]) }\end{array}$ & $\begin{array}{l}\text { Severely affected girl, with pulmonary emphysema and } \\
\text { recurrent chest infection }\end{array}$ & Parents consanguineous \\
\hline $\begin{array}{l}\text { Goltz et al (1965) } \\
\text { Two brothers with loose skin, emphysema and cor } \\
\text { pulmonale; younger brother died at 15 months from } \\
\text { cardiorespiratory complications }\end{array}$ & Parents and sister normal \\
\hline $\begin{array}{l}\text { K. Aterman (personal } \\
\text { communication) }\end{array}$ & $\begin{array}{l}\text { Three affected brothers each with gross cutaneous } \\
\text { laxity and massive aneurysm of the ascending aorta; } \\
\text { all died in infancy }\end{array}$ & Parents and one brother normal \\
\hline
\end{tabular}

It is also of interest that although the skin laxity was usually noted in infancy, in some instances the changes were delayed until adult life (Graf, 1836; Rossbach, 1884). This late onset had also been observed in other affected individuals (Bettman, 1955; Reed, Horowitz, and Beighton, 1971), and it is possible that they have a distinct variety of the disorder. On the other hand, variable penetrance of the gene could account for this variability in clinical manifestations.

Schreiber and Tilley (1961) published an extensive pedigree of an affected kindred, in which there was clear evidence of dominant inheritance. However, from their case descriptions, it seems that these patients had the acromegaloid-cutis verticis gyrata-corneal leukoma syndrome of Rosenthal and Kloepfer (1962), rather than true cutis laxa. Similarly, the family described by Wiener (1925) almost certainly had the Ehlers-Danlos syndrome. Notwithstanding these latter kindreds, there is still substantial evidence to indicate the existence of a benign form of cutis laxa, which is inherited as an autosomal dominant trait.

The presence of major degrees of parental consanguinity in kindreds 3 and 4 (see Fig. 3 ) is strongly suggestive of an autosomal recessive mode of inheritance of the trait. This viewpoint is supported by the absence of the disorder in the parents or other members of the kindreds.

Previously reported cases in which there is evidence of autosomal recessive inheritance are shown in Table II. In the majority of these individuals, the dermal changes were severe and cardiac or pulmonary involvement was frequent. Many of them died during childhood from cardiorespiratory complications.

The affected sisters who were reported by Fittke (1942) and later restudied by Theopold and
Wildhack (1951) have frequently been quoted as examples of recessively inherited cutis laxa, but in view of their concomittant skeletal abnormalities it is more likely that they had the rare disorder which was described Debré, Marie, and Seringe (1937).

Although the total number of cases are few, the available evidence points strongly to the existence of dominant and recessive forms of cutis laxa as separate and distinct entities. In the kindreds described in this paper, and those culled from the literature, the dominant form of cutis laxa has always been benign, with little in the way of systemic ramifications. On the other hand, the dermal and systemic manifestations have been consistently severe in the recessive variety.

In recent years, many uncommon disorders have been shown to be heterogeneous. The dominant forms are usually relatively harmless while the recessive types tend to have serious consequences (McKusick, 1966). The nature of the dominant and recessive forms of cutis laxa is in accordance with this principal.

The elegant histological and electron microscopical studies of Goltz et al (1965) have indicated that the elastin is abnormal in cutis laxa. Investigation of the physical properties of the skin of affected individuals have supported this viewpoint (Grahame and Beighton, 1971). As in other inherited connective tissue disorders, it is possible that there is an abnormality or substitution of an amino acid in the polypeptide chain of the elastin molecule in the dominant variety. In the recessive form, an enzyme defect may be present. As yet, however, the nature of the primary defect is unknown.

The delineation of the dominant and recessive forms of cutis laxa is of importance in genetic counselling and clinical prognostication. Eventually, when suitable techniques become available, 
it may serve as a basis for the recognition of an affected fetus in utero in the dominant variety of the condition, and of the heterozygous carrier of the abnormal gene in the recessive form of cutis laxa.

\section{Summary}

The hypothesis that there are separate autosomal dominant and autosomal recessive varieties of genetically determined cutis laxa is supported by case reports and a review of the world literature.

In the dominant form, the changes are mild and largely confined to the dermis. Conversely, in the recessive type of cutis laxa, the skin lesions are severe and pulmonary and cardiovascular involvement is common. In this type of the condition, these complications often lead to death during childhood.

My thanks are due to Dr Florence Char of Little Rock, Dr R. Prosser of the Royal Gwent Hospital, Newport, and Dr N. Hay of Liverpool for their kind permission to publish the details of patients in their care.

Miss G. Winch HV, SRN (now Mrs G. Beighton) played an important part in the preliminary investigation and later typed the manuscript with enthusiasm and efficiency.

The author was supported by a grant from the St Thomas' Hospital Endowment Fund.

\section{REFERENCES}

Balboni, F. A. (1963). Cutis laxa and multiple vascular anomalies. Bulletin of the St Francis Hospital, 19, 26-34.

Beighton, P. H. (1970). The Ehlers-Danlos Syndrome, 1st ed., p. 1200. Heinemann, London.

Beighton, P. H., Bull, J. S., and Edgerton, M. (1970). Plastic surgery in cutis laxa. British fournal of Plastic Surgery, 23, 285290.
Bettman, A. G. (1955). Excessively relaxed skin and the pituitary gland. Plastic and Reconstructive Surgery, 15, 489-501.

Cashman, M. E. (1957). Cutis laxa-case demonstration. Proceedings of the Royal Society of Medicine, 50, 719-720.

Debré, R., Marie, J., and Seringe, P. (1937). 'Cutis Laxa' avec dystrophies osseuses. Bulletin et Memoires de la Société de Médecine de Paris, 53, 1038-1039.

Fittke, H. (1942). Über eine ungewöhnliche Form 'Multipler Erbabartung' (Chalodermie and Dysosteose). Zeitschrift für Kinderheilkunde, 63, 510-523.

Goltz, R. W., Hult, A. M., Goldfarb, M., and Gorlin, R. J. (1965). Cutis laxa-a manifestation of generalised elastolysis. Archives of Dermatology, 92, 373-387.

Graf (1836). Ortliche erbliche Erschliffung der Hawr. Wochenschrift für die gesammte Heilkunde (Berlin), 15, 225-230.

Grahame, R. and Beighton, P. (1971). The physical properties of skin in cutis laxa. British fournal of Dermatology, 84, 326-329.

Hayden, J. G., Talner, N. S., and Klaus, S. N. (1968). Cutis laxa associated with pulmonary artery stenosis. Fournal of Pediatrics, 72, 506-509.

Kopp, W. (1888). Demonstration zweier Fälle von Cutis Laxa (Vater und Sohn). Münchener medizinische $W$ ochenschrift, 35, 259-260.

Lewis, E. (1948). Cutis laxa. Proceedings of the Royal Society of Medicine, 41, 864-865.

Marshall, J., Vogelpoel, L., and Weber, H. W. (1960). Primary elastolysis. South African Medical fournal, 34, 721-727.

McKusick, V. A. (1966). Heritable Disorders of Connective Tissue, 3rd ed, p. 5. Mosby, St Louis and London.

Reed, W. B., Horowitz, R. A., and Beighton, P. H. (1971). Acquired cutis laxa. Archives of Dermatology, 103, 661-669.

Reidy, J. P. (1963). Cutis hyperelastica (Ehlers-Danlos) and cutis laxa. British fournal of Plastic Surgery, 16, 84-94.

Rosenthal, J. W. and Kloepfer, H. W. (1962). An acromegaloid, cutis verticis gyrata, corneal leukoma syndrome, a new medical entity. Archives of Ophthalmology, 68, 722-726.

Rossbach, M. J. (1884). Ein merkwürdiger Fall von greisenhafter Veränderung der allgemeinen Korperdäcke bei einem achtzehnjährigen Jüngling. Deutsches Archiv für Klinische Medizin, 36, 197-202.

Schreiber, M. M. and Tilley, J. C. (1961). Cutis laxa. Archives of Dermatology, 84, 266-272.

Sestak, Z. (1962). Ehlers-Danlos syndrome and cutis laxa: an account of families in the Oxford area. Annals of Human Genetics, 25, 313-321.

Siegmund, H. (1938). Utber das sog. Oedema lymphangiectaticum. Zentralblatt für allgemeine Pathologie und pathologische Anatomie, 70, 243-247.

Talbot, F. B. (1923). Metabolism study of a case simulating premature senility. Monatsschrift für Kinderheilkunde, 25, 643-646.

Theopold, W. and Wildhack, R. (1951). Dermatochalasis in Rahmen multipler Abartungen. Monatsschrift für Kinderheilkunde, 99, 213-218.

Wiener, K. (1925). Gummihaut (cutis laxa) mit dominanter Vererbung. Archiv fïr Dermatologie und Syphilis, 148, 599-601. 